\title{
Technology Needs Assessment for New Normal Education in Public Elementary School in Clarin, Bohol
}

\author{
Alme B. Maravillas ${ }^{1}$, Romar B. Dinoy ${ }^{2}$, Ariel Christian C. Viodor ${ }^{3}$, Margie V. Avenido ${ }^{4}$, \\ Ramil S. Bulilan ${ }^{5}$, Flora Mae A. Bantilan ${ }^{6}$ \\ ${ }^{1,3,4}$ College of Technology and Allied Sciences, Bohol Island State University -Clarin, Poblacion Norte, Clarin, Bohol, \\ Philippines \\ ${ }^{2,5,6}$ College of Teachers Education, Bohol Island State University -Clarin, Poblacion Norte, Clarin, Bohol, Philippines
}

Received: 03 Oct 2021; Received in revised form: 11 Nov 2021; Accepted: 22 Nov 2021; Available online: 04 Dec 2021

(C)2021 The Author(s). Published by Infogain Publication. This is an open access article under the CC BY license

(https://creativecommons.org/licenses/by/4.0/).

\begin{abstract}
Technology needs assessment is essential part in providing quality education. It aims to identify the existing problems and provides appropriate intervention through giving information. This study aims to assess the technology needs of the public elementary school of Clarin, Bohol for the new normal teaching and learning. The researchers used adopted questionnaires as a tool in assessing the technology needs assessment. The questionnaire was divided into three parts: part 1 deals with assessing their skills level in using technologies and integration of new tools for new normal in teaching; part 2 for the perception towards the challenges in using the technologies; and part 3 deals with assessing the professional development of the teachers. The collected data were analyzed by using descriptive statistics, mean, and standard deviation. The interpretation was also used in the content analysis. It was found out that the level of skills assessment in using technology by the teachers was average level and beginner level for the overall competency in integrating computer technologies. Moreover, slow internet connection, lack of computers, inadequate software to use, and limited time to practice were also identified as the major obstacle. Lastly, adapting the use of technologies for instructional purposes for the new normal education slightly influences the teacher's professional development. Thus, an appropriate action plan must be undertaken to enhance the teaching and address these needs.
\end{abstract}

Keywords - assessment, needs assessment, new normal, technology integration

\section{INTRODUCTION}

With the integration of technology, there has been increasing growth in education for the past years. The educators can have the opportunities to learn and adapt it to their current practice. However, the technology integration varies between the educators due to numerous reasons. Recently, the emergence of COVID-19 continues to spread to this day throughout the world. Many institutions have established their protocols, plans, and procedures to respond to the crisis. It significantly affects the lifestyle, economy, and especially in the educational sectors. Hence, the Department of Education is trying to address this concern amid the pandemic, looking for a way to continue to educate the young minds of the learners. As a result, the 'new normal' for education has finally been implemented. In response to this situation, educators are required to adapt to new transitions in education. There is a sudden shift from face-to-face learning interaction to online flexible learning is a thing unprepared. This transition has brought a great challenge for educators.

The use of new technology for new normal education could not be implemented effectively in an instant, it requires proper training and assessment to adopt the 
technology. The sudden changes have forced teachers to master technology and explore ways to integrate it into their craft to maintain still or be better in delivering quality instruction to every learner. This transition to the new normal, from the four corners of the classroom to the borders of virtual reality, every learning institution needs to study how successful online learning is in providing quality education and outcomes-based education to students [4]. These problems have led the researchers to assess the technology needs for new normal in education in teaching and learning for the public elementary teachers in Clarin. This study could be a great benefit to the respondents for the enhancement program that would be proposed based on the study's findings.

Technology assessment is often referred to as a form of policy research. It examines the short and long consequences of the use of technology [1]. Technology needs assessment aims to provide the policymakers with information and insights on the policy alternatives. The role of needs assessment is to provide information in making data-driven and responsive recommendations in solving the problem or improving the performance [17].

There is a need to conduct an assessment before implementing any educational intervention. Conducting needs assessment is the first step in setting the goals and making strategic plans. Needs assessment is defined as a formal process in determining the gaps between the current output and desired output [2]. At the same time, the term "need" defines the gap between current output and desired output. The term assessment is often associated with the word analysis; hence they are both different. Needs assessment is used to identify the gap between the current output and desired output, while the analysis is the investigation of the factors which cause the existence of the said gap [8]. Hence, needs assessment and analysis are both required in developing the educational intervention. The goal of assessment needs is twofold: (1) ascertain existing capabilities and (2) determine the gap that exists [4]. With these goals, the needs assessment is essential in identifying the main problems and providing appropriate intervention through information [3].

There are five steps in conducting a technology needs assessment [13]. Determining the purposes based on initiators is the first step. These include identifying the performance problems, introducing the new stuff such as technologies, policies and software, and the mandates. Identifying the sources is the next step. There are numerous things to identify the sources, such as determining the needed information, the location, the constraint in getting the data, and the people involved. Selecting the best tools and techniques is the next step. These tools can be observing the employee's performance, interviewing, facilitating groups, examining the records and outcomes, and surveying through questionnaires [18]. The next step is to conduct the assessment in stages. This means that it is not necessary to conduct the assessment at once. It is wiser to conduct stages of assessment. Lastly, use the findings for decision-making [13].

The study shows the importance of needs assessment in identifying the educator's technology needs, acquiring desired hardware and software, and ongoing professional growth [15]. The rapid training of the teachers to the different technologies and software due to the COVID pandemic has been a challenge. Research validates the lack of training and time were identified as common barriers in online education. Most educators prefer workshops as a mode of training for their learning needs [3]. There were also issues faced by the students in online learning. To overcome these issues, studies reveal that it is important to engage the students in collaborative activities in their online learning [14].

The result of technology needs assessment has been implemented in various institutions for the past years. This was conducted to improve the quality of education and student outcome. Research studies show that needs assessments highlight the current needs of the learning facilities and resources in the school [5]. Thus, an action plan must be crafted to address these needs specifically on the student's development and services, school environment, and professional development [6].

In addition, technology integration training has been identified as the key to the technology adoption process [9]. There is a growing interest in the integration of technology in the teaching and learning of students. Various trainings and workshops have been conducted to develop in-service teacher training processes that will strengthen the integration of technology in the classroom. But many factors affect this integration. The direct and indirect effects of teachers' characteristics and perceptions of environmental factors do not correlate with the integration of technology in the classroom. Studies reveal that teachers who received technology-related training tend to have a higher level of technology integration than those who did not undergo any professional development [10]. However, the lack of experience in using the technology in the integration into their teaching has led the educators to avoid the usage of technology entirely [11]. Research findings show that teachers' perception of the use of technology is a factor that affects technology integration. This means that if the teachers have a positive belief in using the technology, the teachers are more likely to adopt the use of technology and apply it effectively [12]. 
The teachers' roles in shaping the minds of learners during the covid pandemic become more complex. The teachers today are expected to become technology-oriented, more co-operators, collaborators, open-minded, critical independent professionals, and facilitators who will help students analyze the quality of new sources and how to learn in a digital environment [20]. The importance of teachers' digital literacy showed that modern education requires teachers who develop their knowledge, skills, and digital literacy [19]. Teachers can help students create, locate, and communicate digital content ethically and adequately with the mentioned literacy.

The above literature reviews highlight the importance of technology needs assessment and the several barriers affecting the teacher technology adoption process. Thus, this paper aims to identify the current needs in Bonbon Elementary school in teaching and learning during the COVID pandemic. Moreover, an action plan should be proposed to address the identified needs of the school.

The study's main objective is to assess the needs of technology for the new normal in teaching and learning for the public elementary school teachers of Bonbon Elementary School in the academic year 2020-2021. This study will be a great help for the teachers since the result of this study will serve as the basis for conducting workshops and training.

\section{OBJECTIVES OF THE STUDY}

The study's main objective is to assess the needs of technology for the new normal in teaching and learning for the public elementary school teachers at Bonbon Elementary School in the academic year 2020-2021. This study will be a great help for the teachers since the result of this study will serve as the basis for conducting workshops and training.

Specifically, the study sought to answer the following questions in terms of:

1. What is the level of self-assessed skills of the teachers in using different tools of technologies for the new normal in teaching and learning?

2. What is the level of the teacher's professional development in using technologies?

3. What are the challenges faced by the teachers in using technologies?

\section{METHODOLOGIES}

The researchers utilized the quantitative research method. Quantitative research is a type of educational research in which the researchers decide what to study, ask specific and narrow questions, collect quantifiable data from participants, analyze data gathered using statistics, and conducts the inquiry in an unbiased, objective manner [7]. The researchers utilized this type of method to describe the perceptions of the elementary school teacher and their technology tools needed for the synchronous and asynchronous kind of learning.

This study was conducted in the identified elementary school of Clarin District, namely Bonbon Elementary School. The researchers included all the teachers at Bonbon Elementary School in determining and assessing the school's technology needs. No sampling method will be used since the respondents will be all public teachers at Bonbon Elementary School. Furthermore, the researchers chose Bonbon Elementary School as the environment of the study because the results of this study will be used as the basis for the conduct of workshops and training to enhance their skills and their familiarity with the new tools to be used for the new normal in teaching.

The researchers adopted the questionnaire developed by Erin N. O'Reilly (2016) in his study 'Developing Technology Needs Assessments for Educational Programs: An Analysis of Eight Key Indicators' at the University of Illinois at Urbana-Champaign, USA as a tool in assessing the technology needs [16]. This study aims to develop a survey questionnaire for technology assessment need in an education setting.

The questionnaire for elementary school teachers has three parts. Part 1 will deal with assessing their skills level in using technologies and the integration of new tools for new normal in teaching. It has rating scales of unfamiliar (1), beginner (2), average (3), advanced (4), and expert (5).

Part II will ask their perception of the challenges they have faced in using technology. The respondents will decide if they are an obstacle (1), minor obstacle (2), and major obstacle (3). While part III deals with the professional development of elementary school teachers. It has a rating scale of no influence (1), slight influence (2), moderate influence (3), and strong influence (4).

\section{RESULTS AND DISCUSSIONS}

This section presents the results, analysis, and interpretation of gathered data on the technology needs assessment at Bonbon Elementary School. Likert scale was used to measure the level of assessment skills of the respondents. It has rating scales of unfamiliar (1), beginner (2), average (3), advanced (4), and expert (5). 
Table 1: Skills Assessment in Using Technologies

\begin{tabular}{|c|c|c|c|}
\hline Statements & SD & $\mathbf{M}$ & DR \\
\hline $\begin{array}{l}\text { I have no experience with } \\
\text { computer technologies. }\end{array}$ & 0.49 & 2.88 & Average \\
\hline $\begin{array}{l}\text { I am able to perform basic } \\
\text { functions in a limited number } \\
\text { of computer applications. I } \\
\text { still require help on a regular } \\
\text { basis. }\end{array}$ & 0.53 & 2.82 & Average \\
\hline $\begin{array}{l}\text { I have general competency in } \\
\text { a number of computer } \\
\text { applications. }\end{array}$ & 0.51 & 2.41 & Beginner \\
\hline $\begin{array}{l}\text { I have acquired the ability to } \\
\text { competently use a broad } \\
\text { spectrum of computer } \\
\text { technologies }\end{array}$ & 0.51 & 2.41 & Beginner \\
\hline $\begin{array}{l}\text { I am extremely proficient in } \\
\text { using a wide variety of } \\
\text { computer technologies }\end{array}$ & 0.51 & 2.41 & Beginner \\
\hline $\begin{array}{l}\text { Word processing software } \\
\text { (e.g., Microsoft Office) }\end{array}$ & 0.43 & 2.94 & Average \\
\hline $\begin{array}{l}\text { Email software (e.g., } \\
\text { Microsoft Outlook, Gmail) }\end{array}$ & 0.47 & 2.71 & Average \\
\hline $\begin{array}{l}\text { Presentation software (e.g., } \\
\text { Microsoft PowerPoint) }\end{array}$ & 0.47 & 2.71 & Average \\
\hline TV Monitor/computer & 0.49 & 2.88 & Average \\
\hline Projector/laptop & 0.49 & 2.88 & Average \\
\hline Multimedia (audio/video) use & 0.47 & 2.71 & Average \\
\hline $\begin{array}{l}\text { I am aware that technology } \\
\text { exists, but do not use it } \\
\text { frequently - perhaps I'm even } \\
\text { avoiding it. I am anxious about } \\
\text { the prospect of using computer } \\
\text { technology. }\end{array}$ & 0.35 & 3.00 & Average \\
\hline $\begin{array}{l}\text { I am currently trying to learn } \\
\text { the basics. I am beginning to } \\
\text { understand the process of } \\
\text { using technology and can } \\
\text { think of specific tasks in } \\
\text { which it might be useful. I am } \\
\text { sometimes frustrated using } \\
\text { computers and I lack } \\
\text { confidence when using them. }\end{array}$ & 0.43 & 2.94 & Average \\
\hline $\begin{array}{l}\text { I am gaining a sense of self - } \\
\text { confidence in using the } \\
\text { computer for specific tasks. I } \\
\text { am starting to feel comfortable }\end{array}$ & 0.50 & 3.00 & Average \\
\hline
\end{tabular}

\begin{tabular}{|c|c|c|c|}
\hline $\begin{array}{l}\text { I think about the computer as } \\
\text { an instructional tool to help } \\
\text { me and I am no longer } \\
\text { concerned about it as } \\
\text { technology. I can use many } \\
\text { different applications. }\end{array}$ & 0.70 & 2.88 & Average \\
\hline $\begin{array}{l}\text { I can apply what I know about } \\
\text { technology in the classroom. I } \\
\text { am able to use it as an } \\
\text { instructional aid and have } \\
\text { integrated my knowledge into } \\
\text { the curriculum }\end{array}$ & 0.56 & 2.94 & Average \\
\hline
\end{tabular}

Table 1 shows the result of the skills assessment of elementary teachers in Bonbon Elementary School using computer technologies and integrating new tools for a new normal mode of teaching. It was shown on the result that the majority of the teachers have an average experience in using and integrating the different technologies that will be used for the new normal mode of teaching. Most of them have an average experience using computer technologies such as word processing software, email software, presentation software. They also have average skills in using tv monitor/computer, projector, and other multimedia software. Moreover, most of the teachers have beginner skills in general competency in utilizing computer applications and using various computer technologies.

Table 2: Perception towards the Challenges in Using Technologies

\begin{tabular}{lccl}
\hline \multicolumn{1}{c}{ Statement } & SD & Mean & DR \\
\hline $\begin{array}{l}\text { Lack of computers in the } \\
\text { classroom }\end{array}$ & 0.61 & 2.35 & $\begin{array}{l}\text { Major } \\
\text { Obstacle }\end{array}$ \\
$\begin{array}{l}\text { Students do not all have equal } \\
\text { access to computers at home }\end{array}$ & 0.60 & 3.00 & $\begin{array}{l}\text { Major } \\
\text { Obstacle }\end{array}$ \\
$\begin{array}{l}\text { The overall technology skills (e.g., } \\
\text { AV recording) of students in my }\end{array}$ & 0.33 & 2.88 & $\begin{array}{l}\text { Major } \\
\text { class vary so widely that it's too } \\
\text { difficult to manage technology } \\
\text { integration }\end{array}$ \\
$\begin{array}{l}\text { My students lack the necessary } \\
\begin{array}{l}\text { English language skills to use } \\
\text { computers efficiently }\end{array}\end{array}$ & 0.51 & 2.47 & $\begin{array}{l}\text { Major } \\
\text { Obstacle }\end{array}$ \\
$\begin{array}{l}\text { Professional development prepares } \\
\text { me to use technology in the } \\
\text { classroom, but I do not have } \\
\text { enough time to practice }\end{array}$ & 0.39 & 2.18 & $\begin{array}{l}\text { Major } \\
\text { Obstacle }\end{array}$ \\
\hline
\end{tabular}




\begin{tabular}{lccl}
\hline $\begin{array}{l}\text { Insufficient or inadequate software } \\
\text { on classroom or laptop computers. }\end{array}$ & 0.51 & 2.47 & $\begin{array}{l}\text { Major } \\
\text { Obstacle }\end{array}$ \\
$\begin{array}{l}\text { Internet is too slow or drops } \\
\text { connection }\end{array}$ & 0.49 & 2.65 & $\begin{array}{l}\text { Major } \\
\text { Obstacle }\end{array}$ \\
\hline
\end{tabular}

Table 2 shows the results of the teacher's perception of the challenges in using technologies. It was found out that the teachers have unanimously rated the lack of computers in the classroom as one of the major obstacles in the new normal in teaching and learning education. Moreover, most of the students do not have equal access to computers at home; they lack technology skills and English language skills to use computers are also identified as major obstacle. Most of the teachers rated that they didn't have enough time to practice using different technologies as one of the major obstacles. Lastly, poor internet connection was also identified as major obstacle.

Table 3: Professional Development

\begin{tabular}{|c|c|c|c|}
\hline Statement & SD & Mean & DR \\
\hline $\begin{array}{l}\text { Managing my computer } \\
\text { desktop (opening } \\
\text { programs, printing, etc.) }\end{array}$ & 0.83 & 3.06 & $\begin{array}{l}\text { Moderate } \\
\text { Influence }\end{array}$ \\
\hline $\begin{array}{l}\text { Learning to utilize } \\
\text { network services } \\
\text { efficiently (email, saving } \\
\text { to the server, finding files, } \\
\text { etc.) }\end{array}$ & 0.70 & 2.88 & $\begin{array}{l}\text { Moderate } \\
\text { Influence }\end{array}$ \\
\hline $\begin{array}{l}\text { Learning about research } \\
\text { sources on the internet }\end{array}$ & 0.56 & 2.94 & $\begin{array}{l}\text { Moderate } \\
\text { Influence }\end{array}$ \\
\hline $\begin{array}{l}\text { Integrating technology } \\
\text { into my classroom } \\
\text { activities }\end{array}$ & 0.80 & 2.59 & $\begin{array}{l}\text { Moderate } \\
\text { Influence }\end{array}$ \\
\hline $\begin{array}{l}\text { Learning specific } \\
\text { applications/software. }\end{array}$ & 0.70 & 2.65 & $\begin{array}{l}\text { Moderate } \\
\text { Influence }\end{array}$ \\
\hline $\begin{array}{l}\text { Learning to integrate } \\
\text { technology for homework } \\
\text { assignments }\end{array}$ & 0.72 & 2.47 & $\begin{array}{l}\text { Slight } \\
\text { Influence }\end{array}$ \\
\hline $\begin{array}{l}\text { Learning how to create } \\
\text { videos of students for } \\
\text { assessment/evaluation }\end{array}$ & 0.62 & 2.41 & $\begin{array}{l}\text { Slight } \\
\text { Influence }\end{array}$ \\
\hline $\begin{array}{l}\text { Learning to create } \\
\text { multimedia (e.g., video } \\
\text { editing and formatting) for } \\
\text { instructional use }\end{array}$ & 0.72 & 2.53 & $\begin{array}{l}\text { Moderate } \\
\text { Influence }\end{array}$ \\
\hline
\end{tabular}

Table 3.0 shows the result of teachers' professional development with the use of technologies. Most of the respondents unanimously rated as moderately influence such as managing the computer desktop (3.06), utilizing the network services efficiently (2.88), learning on research resources on the internet (2.94), integrating technologies (2.59), learning specific applications/software (2.65), and learning to create multimedia (2.53). At the same time, the statements on learning to integrate technology for homework assignments (2.47) and learning how to create videos of students for assessment/evaluation (2.41) as slight influence on their professional development.

\section{CONCLUSION}

Based on the finding, the following conclusions were drawn:

1. Most of the teachers has an average skill in using different software such as word processing, email software, presentation software, projector/laptop, and multimedia software. Moreover, the teachers have beginner skills in terms of the overall competency in integrating computer technologies.

2. Most of the challenges were considered as major obstacles such as slow internet connection, lack of computers, inadequate software, students don't have equal access of the internet, lack of English skills for the students, and limited time to practice for the newly introduced technologies for the new normal education.

3. Integrating and adapting the use of technologies for instructional purposes for the new normal education have a slight influence on the teacher's professional development.

\section{RECOMMENDATION}

To utilize the findings of the study, the researchers recommended the following:

1. Conduct intensive seminars and workshops related to integrating and using the different technologies/software in teaching and learning for new normal education and encourage the teachers to attend the said activities.

2. The teachers may encourage to use the ICT facilities provided by their schools or to purchase ICT for their own benefit.

3. Acquisition of WIFI hotspot to solve the problem of slow internet connection.

4. Acquisition of additional computers/laptops and projectors.

5. For future studies, researchers may investigate the effects of integration of ICT for this new normal education. 


\section{REFERENCES}

[1] Altschuld, J. W., \& Lepicki, T. L. (2009). Needs assessment. Handbook of Improving Performance in the Workplace: Volumes 1-3, 771-791.

[2] Barkat, M., \& Saeed, G. A. (2021). Covid-19 e Pinnacle of Technology Enhanced Teaching-Faculty Needs Assessment. In PROCEEDING ICME 2021 VIRTUAL CONFERENCE--Excellence in Health Profession Education; Through Globalization \& Collaboration (p. 151).

[3] Basilaia, Giorgi \& Kvavadze, David. (2020). Transition to Online Education in Schools during a SARS-CoV-2 Coronavirus (COVID-19) Pandemic in Georgia. Pedagogical Research. 5. 1-9. 10.29333/pr/7937.

[4] Black, Paul \& Wiliam, Dylan. (2010). Inside the Black Box Raising Standards Through Classroom Assessment. Retrieve from:http://lst-iiep.iiep-unesco.org/cgibin/wwwi32.exe/[in=epidoc1.in]/?t2000=022921/(100).

[5] Dinoy, R. B., Beltran, R. A., Bulilan, R. S., Vito, M., Viodor, A. C., Monalim, J. A., \& Ombajin, B. M. (2020). Needs Assessment in Danahao Integrated School

[6] Fischler, A. S. (2010). Quantitative research methods. Science, 1-15.

[7] Garira, E. (2020). Needs assessment for the development of educational interventions to improve quality of education: A case of Zimbabwean primary schools. Social Sciences \& Humanities Open, 2(1), 100020.

[8] Guzman, M. A., \& Nussbaum, M. (2009). Teaching competencies for technology integration in the classroom. Journal of Computer Assisted Learning, 25, 453-469.

[9] Hastings, T. A. (2009). Factors that predict quality classroom technology use (Doctoral dissertation, Bowling Green State University).

[10] Inan, F., \& Lowther, D. (2010). Factors affecting technology integration in K-12 classrooms: A path model. Educational Technology Research and Development, 58(2), 137-154.

[11] Kagan, D. M. (1992). Implication of research on teacher belief. Educational psychologist, 27(1), 65-90.

[12] Kaufman, R. (1977). Needs assessment. Educational Technology, 17(11), 4-64.

[13] Kazm F., Ray , P., Damodharan, S., \& Sreedharan, J. (2021). Online Learning on Medical Students, Challenges and Strategies: Cross-Sectional Study in the UAE. International Conference on Medical Education, 161-167

[14] Kocher, A. T., \& Moore, B. 2001. "Assessing teacher technology skills", Paper presented at the Annual Meeting of the American Educational Research Association, Seattle, WA

[15] O'Reilly, E. (2016). Developing technology needs assessments for educational programs: An analysis of eight key indicators. International Journal of Education and Development using ICT, 12(1).

[16] Rossett, A. (1995). Needs assessment. Instructional technology: Past, present, and future, 183-196.

[17] Southwest Comprehensive Center. 2008. A guide for comprehensive needs assessment [online]. Available at: https://www.cde.state.co.us/sites/default/files/documents/fed programs/dl/ consapp_na_guide.pdf [Accessed: 22 May 2015].
[18] Vidosavljevic, Milena. (2019). La comunidad sefardí en Pirot. 479-494. 10.18485/hispserb.2019.2.ch27.

[19] Weinberger, Armin \& Reiserer, Markus \& Ertl, Bernhard \& Fischer, Frank \& Mandl, Heinz. (2016). Weinberger, Reiserer, Ertl, Fischer, Mandl Facilitating collaborative knowledge construction in computer-mediated learning environments with cooperation scripts 2003. 